\title{
REFLECTIONS ON THE WOODHOUSE LEGACY FOR THE 21ST CENTURY
}

\author{
Susan St John*
}

This lecture commemorates the life of one of our most distinguished judges and citizens, Sir Owen Woodhouse. His compassion, generosity of spirit and social conscience were reflected in his work as President of the Court of Appeal, President of the Law Commission and Chairman of the Royal Commission on Compensation for Injury that recommended a no-fault accident compensation scheme and laid the foundations for the Accident Compensation Corporation (ACC) scheme. He made an immense contribution to New Zealand's law and society.

The Sir Owen Woodhouse legacy can be described as a "paradigm shift" in the thinking around compensation for accidents, prevention and rehabilitation. The 1967 report provided a no-fault compensation benchmark blueprint for New Zealand, ${ }^{1}$ and the subsequent ACC legislation has been admired, if not fully adopted by other countries. Enduringly today, the Woodhouse principles and thinking are influencing the next paradigm shift that is occurring in welfare. The widespread reform needed requires relinquishing 19th century thinking to embrace a modern inclusive well-being focused welfare state fit for the changing roles of women, work and uncertainty in the 21 st century. A paradigm shift is a "disjunctive process associated with periodic discontinuities in policy". ${ }^{2}$ It requires the world to be viewed in a different way and thus paradigm changes are painful, resisted and often subject to reversionary changes. Nevertheless, they are the way in which progress is made. The lesson since the ACC scheme began is that entrenched thinking dies hard and clear guiding principles can be easily lost. The Owen Woodhouse vision that moves us to a unified welfare system requires eternal vigilance, education of policy makers and the public and a resolve not to slip back into old habitual thinking.

* Associate Professor of Economics, Director of the Retirement Policy and Research Centre, Business School University of Auckland. The Sir Owen Woodhouse Memorial Lecture, delivered to Victoria University of Wellington on 16 October 2019 and Auckland University on 22 October 2019.

1 Compensation for Personal Injury in New Zealand: Report of the Royal Commission of Inquiry (Government Printer, December 1967).

2 Peter Hall "Policy Paradigms, Social Learning, and the State: The Case of Economic Policymaking in Britain" (1993) 25 Comparative Politics 275 at 279. 


\section{INTRODUCTION}

I am honoured and delighted to have been asked by the Woodhouse family to deliver the third Woodhouse memorial lecture. The first memorial lecture was Sir Kenneth Keith's, "Out of this nettle, danger we pluck the flower, safety: promoting safety through law, national and international, and by other means", 3 and the second Sir Geoffrey Palmer's, "A retrospective on the Woodhouse report: the vision, the performance and the future". ${ }^{4}$ I follow with trepidation in the footsteps of these giants.

I am also conscious of the many whose contribution has helped sustain, improve and protect the Woodhouse legacy. I am particularly indebted to Alan Clayton, Richard Gaskins, Don Rennie, Michael Timmins, Richard Madden, Grant Duncan, Brian Easton, Felicity Lam, Hazel Armstrong, Warren Forster to name but a few, and all the members of the ACC Futures Coalition that has been set up to promote and protect the Woodhouse principles.

In revisiting the remarkable contribution of Sir Owen, I have been struck by the wealth of analysis and sheer volume of literature that has emerged over the past 50 years. Are there still things left to say? I do not pretend to bring legal expertise to tonight's lecture, but I want to reflect on the Woodhouse legacy as an economist, a policy advocate and a woman in the context of the fraught policy environment of the 21 st century that cries out for the next paradigm shift.

Like many others who work in public policy I am greatly indebted to the Woodhouse vision. He provided the gold standard of how to do good policy work. There have been many occasions when I have been honoured to be part of events that have examined his path breaking work in light of current developments.

One such event was the 40 year anniversary of the publication of the 1967 report; ${ }^{5}$ a very happy celebration with a cutting of the cake by Sir Owen. For that occasion, the University of Auckland digitalised and reprinted the entire 1967 report. At that event, now retired Supreme Court Judge Sir Ted Thomas recalled these words from a speech he made in 1969: ${ }^{6}$

3 Kenneth J Keith "Out of this nettle, danger, we pluck this flower, safety: Promoting safety through law, national and international, and by other means" (Sir Owen Woodhouse Memorial Lecture, University of Auckland, Auckland, 30 August 2017). See also Kenneth Keith "Promoting Safety Through Law, National and International, and by Other Means" (2018) 49 VUWLR 229.

4 Geoffrey Palmer "A Retrospective on the Woodhouse Report: The Vision, the Performance and the Future" (Sir Owen Woodhouse Memorial Lecture, Victoria University of Wellington, Wellington, 10 September 2018). See also Geoffrey Palmer "A Retrospective on the Woodhouse Report: The Vision, the Performance and the Future" (2019) 50 VUWLR 401.

5 Compensation for Personal Injury in New Zealand: Report of the Royal Commission of Inquiry, above $\mathrm{n} 1$.

6 For the recollection see Ted Thomas "Tribute to Sir Owen Woodhouse" (speech to Accident Compensation: Forty Years on - a Celebration of the Woodhouse Report Symposium, University of Auckland, Auckland, 13 December 2007). 
This beautifully crafted Report is the work of a man with a deep-rooted social conscience fully aware of the needs and aspirations of the common man and woman [importantly]. His Report reflects his vision of a more humane, harmonious and responsible society. As such, it represents the most far-reaching exhortation to the community to engage significantly with those who are less fortunate since the enactment of the Social Security Act in 1938.

Fifty two years ago, Owen Woodhouse offered a paradigm leap that went well beyond the Royal Commission's narrow terms of reference he had been given. In doing so he wanted to create a scheme for mitigating the inequality and injustice inherent in free market insurance arrangements. Tonight, in that light, I will examine New Zealand's three major social programmes: ACC, New Zealand Superannuation (NZ Super) and welfare, including Working for Families. While they each have, as their fundamental reason for being, the improved justice and equality for the less fortunate, they form a highly incoherent system of income maintenance.

A comparison of state expenditure on each programme shows the dominance of NZ Super. NZ Super is 44 per cent of a total spend of $\$ 33$ billion, well ahead of core benefits and Working for families (28 per cent) and ACC (13.6 per cent). ${ }^{7}$ As Sir Geoffrey's lecture last year so clearly explained, ${ }^{8}$ the different treatment of people who have equal need, but their disability has different causes has become utterly intolerable. It is painfully clear that the welfare system of benefits is no longer fit for purpose. Social disintegration, rapidly rising inequality, homelessness, child poverty, return of third world diseases and injustice have not yet produced a sense of urgency or an irresistible social pressure for the next paradigm shift. I argue tonight that our systems of income maintenance can be made more coherent and humane, if we have the courage to look at the three systems as a whole, and reinterpret the Owen Woodhouse principles for the 21 st century.

\section{PARADIGM SHIFTS}

Paradigm shifts are light bulb moments: the earth is not flat; the sun does not go around the earth. A mind once expanded by the new conceptual thinking cannot return to its previous contracted unconscious state. So it was with the paradigm shift that Woodhouse demanded. All the more remarkable, this came not from some left wing lunatic socialists, but came with support of the legal profession, many of whom would be severely disadvantaged by the abolition of the right to sue.

Sir Owen challenged the old fault and insurance based paradigm. The "forensic lottery" of the former arrangements does not need labouring for this audience tonight. In essence, the common law could award compensation but only for proven fault and even that could be lessened for contributory

7 Authors calculations based on Budget 2019. ACC includes treatment and rehabilitation spending. Supplementary welfare makes up the balance of expenditure (14.2 per cent) and comprises assorted subsidies and means-tested top ups.

8 See Palmer, above n 4. 
negligence. While there was no-fault compensation for work accidents, it was very limited. A subsistence welfare benefit awaited those who fell outside these parameters.

The famous Woodhouse principles for the paradigm shift were truly radical. Community responsibility not individual responsibility was key. Comprehensive entitlement meant coverage of all accidents, even for "housewives". Complete rehabilitation and real compensation were generous concepts. And above all administrative efficiency meant that it could be provided simply and at no greater cost than the previous inequitable arrangements.

But there was much opposition: not all in legal circles were pleased, nor was the insurance industry and even trade unions saw merit in being able to sue negligent employers. The average person probably had little inkling of how bad the common law arrangements were, and not all were willing to have their minds expanded by the radical Woodhouse vision.

The full paradigm shift required that it should not matter if the accident was work related, if the injured was employed, whose fault it was or when or where it happened. Woodhouse argued that private insurance principles should be replaced by inclusive and expansive social insurance principles. This was the paradigm shift:

- a state compulsory social contract;

- flat rate levies because all economic activity is inter-related;

- $\quad$ timely and adequate compensation, separated from prevention; and

- no actuarial based funding required; some reserves held for prudence as the scheme built up.

Paradigm shifts can be painful; they require the world to be viewed in a different way. When thinking is reactionary and highly entrenched, especially when there are economists around, backsliding is inevitable. Even at first, some of the insurance trappings of the old workers' compensation thinking were just too powerful to be relinquished and were carried over to the new legislation. Then in the 1980s and 1990s a neoliberal market economics paradigm took hold within New Zealand.

Coming under this new and extreme thinking, ACC was to be transformed into a "fairer" scheme, emphasising individual responsibility, choice, private insurance, a reduced role for the state and the primacy of paid work as the goal.

The powerful resistance to the Woodhouse paradigm shift was amplified in numerous attempts to reform ACC to reflect private insurance principles and conform with the imposed economics paradigm. The language was changed with the insertion of the term "insurance" into the name of the Act, which became the Accident Rehabilitation and Compensation Insurance Act 1992; levies were even renamed "premiums" at one point. The Accident Compensation Commission became a "Corporation" with a board focusing on cost minimisation. Various amendments reduced coverage and tightened the fine print insurance contractual approach where recourse to the courts was the way to challenge ACC decisions. Experience rating to modify risk related levies by rewarding the good 
and punishing the bad employers was supposed to provide a safety incentive. By 1998 the scheme was set up for privatisation of the work account based on the economist's blind belief in the value of having competing insurance providers.

\section{ACC-MY EXPERIENCE}

I want to take this opportunity to here to insert my own experience of the Woodhouse vision as a young academic and acknowledge my personal debt to Sir Owen. Back in the 1970s I had returned to the university for a degree in economics, while I raised children.

I found the constraints of traditional economics almost unbearable with its growing free market bias, and I became interested in the concepts of the social wage, and in social insurance. I must have seemed a bit of an oddity to Sir Owen Woodhouse, as a young, pregnant, female economist, but he was extremely helpful and encouraging. During the late 1970s we had many in depth discussions about ACC, especially the role of the cumbersome differential levy system whereby different industries or groupings had different levies that were supposed to reflect the risk. Carrying that levy system over from the old workers' compensation had clearly undermined his insight of the high interdependence we have in the modern world and the need to share the risks involved in the activities that allow our high standard of living.

Back then, I was married to a General Practitioner who practised occupational medicine and serviced Westfield and Southdown Freezing works. ACC had just been introduced with fascinating implications for that high profile, high accident risk industry. I decided to examine the role of levies in accident prevention and the modifications of those levies by rebates and penalties, using the freezing works as a case study. My reasoning was that if experience rating was going to work anywhere it would work in that industry.

To fulfil the requirements of an economics degree it was necessary to have some underpinning statistical basis and very fortunately for me, there was comprehensive accident data for 36 companies published in the 1977 Nordmeyer report on freezing works. ${ }^{9}$

In many industries, accidents are rare events and long periods are required to track any one company's performance. In this industry they were very frequent events so I thought it should be possible to identify the companies whose records were worse or better than the average.

Welfare economics and cost benefit analysis were dominant frameworks. There seemed to be lessons from environmental economics where diagrams (beloved of economists) show that by taxing units of pollution you internalise the externality and bring about an optimal level of pollution

9 Report of Sir Arnold Nordmeyer to the Accident Compensation Corporation as a result of a special enquiry into the nature of, and the extent of incapacity resulting from personal injury by accident or occupational diseases in the freezing industry and the precautions and safety measures which are taken to prevent such accidents and diseases occurring, and other matters related thereto (22 August 1977) [Nordmeyer Report]. 
reduction. Not zero pollution, but only to the point where the cost of reducing pollution by another unit is finely balanced against the benefits of doing so. By analogy, was there an optimal level of accidents and could experience rating bring it about?

I devised a method of comparing these companies in a statistically valid way. Given accidents are random, the industry would have an expected range of numbers of accidents. If a firm's accident frequency was outside the norm, could a rebate/penalty approach incentivise optimal prevention? I assumed that the overall starting levy was correct for this industry (which was unlikely) and asked what kinds of rebate or penalty should apply to each of these companies based on their experience. I came up with some highly contradictory results depending on how accident experience was defined. My fourth child was born at the end of 1977. A few months later I handed my tediously long Master's thesis, pretentiously titled "Cost allocation in the ACC scheme". It felt like I had delivered a fifth child.

But where was the logic in the levies? What I did learn was that the system of levies based on an industry's risk that had been imported from the old workers' compensation scheme was highly questionable, and that trying to make adjustments for good and bad accident experience was a dead end to go down if you cared about safety or even just about equity or accuracy.

The light bulb moment for me was realising that even if nirvana of $\mathrm{MB}=\mathrm{MC}$ can be reached in theory, there is actually a huge and unforgivable sleight of hand. The costs that are internalised are not the true cost of accidents, but only the costs that happen to be there in a particular system of compensation. For example, the costs of a fatal accident can be minimal in this system, simply because there is no way of compensating a dead person apart from his/her dependants. I acknowledge my debt to the perceptive insights of Richard Gaskins who has been a strident critic of the welfare economics approach in ACC and how it focuses on a minimisation of accident prevention costs rather than the needs of the injured and society.

He saw so clearly how the no-fault approach to accidents in the United States was snuffed out by the rise of the seemingly scientific economic paradigm of market based solutions to social problems: ${ }^{10}$

Welfare economics colonised public policy debates in America during the 1960s for many reasons. One major cause was the professional commitment to impartial scientific inquiry at leading universities.

Welfare economics brought nothing in the way of empirical data, but it offered its champions the mantle

of objectivity ... [They] used these analytical tools to insulate their policy prescriptions from standard partisan attack.

The more I thought about it, the sillier the concept of differential levies and experience rating became. A poorly managed construction site that results in injuries to passing pedestrians does not have those costs attributed to them as work accidents. A fire at the site caused by inattention to safety

10 Richard Gaskins "The Fate of 'No-Fault' in America" (2003) 34 VUWLR 213 at 222. 
protocol might result in few actual injuries to the onsite workers, but cause hugely expensive property damage, and injuries and ongoing health issues for the firemen who are not part of the construction industry. Unsafe gym equipment may injure members, not employees. These and many other realities make the allocation of cost of work accidents to the firm that employs workers a nonsense, and increasingly so in a world of intersecting work environments, and where there is a growing fudging of work and non-work space.

Any rebate or penalty has to relate to evidence collected over several years to build a picture of accidents. I was disgusted to see that, shortly after finishing my thesis, the government of the day did proceed with a system of rebates and penalties. In 1980, Air New Zealand received a bonus, despite experiencing the worst aviation accident in New Zealand history in 1979.11

We still have a hugely complex and finely grained set of different levies for different industrial groupings. The different industrial classification units (536) and sub risk groups (130) are set out in a daunting 132 pages of levy tables. ${ }^{12}$ In addition to the employer levy, employees pay for non-work accidents at a flat rate of 1.21 per cent regardless of whether they engage in risky activities or not.

I was horrified to see the idea of experience rating resuscitated in 2011. If small rebates and penalties are applied, they are not worth worrying about. If they are significant, say up to 50 per cent rebate or 100 per cent penalty as was proposed, they just incentivise the limiting of claims, passing off work injuries as non-work and getting people back to work too quickly. They perpetrate complexity by needing to have fully funded accounts that separate work accidents to earners, from non-work accidents to earners, from non-work accidents to non-earners. With Auckland University of Technology (AUT) researchers I examined the proposals to implement experience rating and found them to be complex, incomprehensible and unworkable.

In the meantime, the country experienced three major disasters: The Pike River Mine disaster, the Christchurch earthquakes and the underground explosion in the Watercare Services pipeline, all with serious loss of life and injury - not just to employees. We concluded: "[i]t would be a tragedy for New Zealand to rely on such complex schemes to improve safety while downplaying or ignoring more obvious ways of achieving that end." 13

It is fair to say the ACC has struggled to do experience rating well. Yet astonishingly, we learn from the website that rebates and penalties in an improved experience rating plan are again on the

11 Susan M St John "Safety Incentives in the New Zealand Accident Compensation Scheme" (1981) 15 New Zealand Economic Papers 111.

12 Accident Compensation Corporation ACC Levy Guidebook: Your guide to 2020/21 levy rates and industry classifications.

13 Felicity Lamm, Nadine McDonnell and Susan St John "The Rhetoric versus the Reality: New Zealand's Experience Rating" (2012) 37(2) NJER 21 at 35. 
table. ${ }^{14}$ The true tragedy is that this approach is unchallenged and takes us ever further away from the principles of Woodhouse - it further contaminates ACC with insurance type thinking, introduces enormous complexity, opens up further litigation, impedes further progress to accepting more gradual process injury, occupational disease and mental illness cases as befits our new understandings and sadly diverts the eye from other ways to address safety.

Let us leave the last word on this with Sir Owen: ${ }^{15}$

... from the outset, on the income side of the ledger the whole emphasis was left unchanged. As previously, the cause or location of the accident was made to decide everything. Adopted as a hangover from the days of private insurance, individual trades and businesses have been charged unevenly. Each must meet the estimated cost of injuries expected to occur within its own area of operation ... It is self-evident that these decisions - to collect income based on cause, on who should be held responsible for accidents - have resulted in much subsequent contention about costs and benefits.

\section{FUNDING}

Just as experience rating and differential levies hold back ACC from achieving the Woodhouse vision, so does the insistence on full funding. The beauty of social insurance is that it releases us from the straightjacket of private insurance. While private insurance needs to hold enough reserves to meet all the current obligations in case it goes out of business, full funding has never been necessary for social schemes like ACC, although a build up of reserves in the early years provided a useful buffer. The power of the neoliberal economic paradigm tricked politicians, both left and right, into thinking the same must apply for ACC.

At various times in the last 30 years I have been involved in numerous debates over funding. Here I measure reserves in terms of the number of months expenditure held in the fund. The reserves have fluctuated markedly depending on the prevailing power of the market paradigm. ${ }^{16}$

In 1997 Rt Hon Jim Bolger said that full funding was necessary for the next step which was privatisation of the work account and introduction of competing insurance companies. Levies increased dramatically and privatisation occurred in 1998. Sadly, even though Labour won the 1999 election and abolished the privatisation experiment, full funding has been the goal of both political parties.

Today the ACC fund is now awash with riches and at around $\$ 42$ billion, or equal to over 100 months of expenditure; it is off the scale. Like Scrooge in the treasure trove, enlarging the fund has

14 See ACC "We've improved Experience Rating for businesses" (1 April 2020) <www.acc.co.nz/forbusiness/business-updates>.

15 Owen Woodhouse "Opening Remarks" (2003) 34 VUWLR 189 at 190.

16 Susan St John "ACC: the lessons from history" (2010) 6(2) PQ 23. 
become a well-paid career path and an end itself. Recently there have been absurd claims that somehow ACC is running a deficit and levies will have to increase - simply because the discount rate has fallen, and this has increased the actuarial calculation of the outstanding liabilities. ${ }^{17}$ One wonders how increased levies will gel with the proposed rebates and penalties.

We have failed to appreciate that social insurance allows us to escape the straightjacket of the fine print of private insurance. The adherence to old thinking: risk related levies, the notion of full actuarial funding, restricted and complex exclusions, a corporate model of administration and an emphasis on cost limitation has inhibited the evolution of ACC that the Owen Woodhouse vision of social insurance invited. "[Actuarial projections as a scientific exercise] is almost as pointless as the debate in mediaeval scholasticisms as to the number of angels that can dance on the end of a pin."18

Sadly, the hope of Sir Owen that wasteful and adversarial court action would disappear has not been realised. He did not want the cause of the disability to determine the response of the state. But over time the boundary war between events that qualify as accidents under the ACC definition and those that do not has intensified. Coverage is extended and then contracted by amendments to the Accident Compensation Act 2001 that reflect the power of the neoliberal paradigm at the time. For example, 2010 amendments reversed the decision to cover suicide, raising yet more boundary issues and seeming inequities: what is suicide and what is accidental death? Desperate people denied coverage may ask the private company FairWay for a review of ACC decisions. The ACC aggressively defend cases taken through the courts and have all the resources behind them. Once again, we have a forensic lottery: those less fortunate are not at the heart of the system.

Let me give just one example, from a dental practice that I know. The regulations around what is covered are horrendously complex - apparently breaking a tooth by biting on something hard is not an accident. Nor is an implant offered when there are other missing teeth. How that improves social equity when poor people are the ones who have poor dental health is hard to fathom.

Just looking at the income maintenance side, because of the miserable nature of the welfare system, it really matters if an event was an accident or not. Or if a gradual process claim fails to be identified with a work injury or disease. Or whether one is earning. Take the example of a young highpowered highly paid male executive on his lime green scooter on the way to work. He collides with a 60 year old woman on her way to her highly valuable unpaid work taking care of grandchildren. She ends up on the supported living payment ( $\$ 11,860$ per annum), which is about 15 per cent of what he gets $(\$ 78,000)$. But worse, she may get less than that, or even nothing if her husband is earning.

17 Marc Daalder "ACC levies likely to rise as fund hits deficit" (25 September 2019) Newsroom <www.newsroom.co.nz>.

18 Alan Clayton "Some Reflections on the Woodhouse and ACC Legacy" (2003) 34 VUWLR 449 at 460. 
Earnings-related compensation is based on an outmoded idea that a person's paid work reflects the value they contribute.

As ACC has got mired in complexity, few questions are raised about the privileging of work injuries or occupational disease experienced by earners, or the insensitivity to the biases that affect Māori, Pasifika, women and other marginalised groups. There is very little appreciation of Posttraumatic Stress Disorder (PTSD), perversely limited coverage for mental injury and the conflation of return to work with rehabilitation.

In 1967 Sir Owen Woodhouse acknowledged the work that "housewives" did in supporting productive activity of others. That was indeed a big step forward for that era. He even proposed a periodic payment in lieu of earnings-related compensation. But women were described as "enabling the productive work of others" and therefore worthy of support. Times have moved on. It is of interest to me that the most productive work and often the most dangerous, is the work of procreation - work done by women. Some of the traumas of birth are never healed and can vastly affect women in a gradual process as they age. Many of these women are struggling to get gynaecological treatment in Aotearoa New Zealand in 2019. If ACC had evolved as social insurance instead of dressed up private insurance, inclusion to reflect new thinking about these things might have occurred.

I have been pondering the contribution of the Owen Woodhouse legacy for the next paradigm shift. I think he would welcome a reinterpretation the principles for the modern world: ${ }^{19}$

As one grows older it is wise to realise that the continuing value of earlier ideas is best assessed by those who will continue to be affected by them ... after a time, patch and repair, however well-intentioned, is likely to obscure the wider needs, together with the principled base which should support them. In relation to benefits, for example, there is the situation of the hardworking housewife who is injured at home or on the highway or indeed anywhere else. In terms of principle, has her entitlement kept pace with that of her hardworking partner who is injured at his place of work, or indeed anywhere else?

The Owen Woodhouse vision of the well-being of anyone injured regardless of circumstances has been replaced by a legalistic, mean spirited corporate and regulatory approach that seeks above all to save costs and that has elevated a return to paid work above the long-term well-being of claimants. I argue tonight this is symptomatic of a deeper malaise - a paralysis of policy making that has seen the judicial system increasingly asked to solve social problems that it is largely incapable of solving. The paradigm shift that is needed today requires the removal of these impediments.

\section{NEW ZEALAND SUPERANNUATION (NZ SUPER)}

Let us briefly examine the other major paradigm shift in the 1970s that has proved remarkably durable and largely immune from attacks from neoliberal economic thinking. The genesis of "national superannuation" as NZ Super was first named, was not some well thought out, highly crafted report

19 Woodhouse, above n 15, at 189-190. 
that had at the heart the well-being of people - as was the Woodhouse 1967 report. To be direct about it - Rt Hon Robert Muldoon wanted to be elected. I am grateful to Sir Geoffrey Palmer for setting out the history in his edited book The Welfare State Today. ${ }^{20}$ If the problem was identified by National at all, it was in terms of the needs of older persons who were suffering hardship as the old superannuation payment was so low. I am also old enough to remember the poverty of old people and the sadness of some neighbours who subsisted on the low-level universal superannuation. Labour's competing 1974 funded compulsory savings scheme was only for future retirees: the poorer old people of the day were ignored.

Using the lens of paradigm shifts, a liveable superannuation was to be provided universally from the public purse, not through individuals saving for themselves. The Labour Government's compulsory personal savings scheme was abolished as we got our contributions back.

Using the criteria of the Woodhouse report, NZ Super ticks all the boxes.

Community responsibility: just as the aim of the ACC was to prevent accidents and to share the costs when they occurred, NZ Super was to prevent poverty and share the costs of old age. It was markedly successful - overnight, poverty of old people dropped away as of concern.

Comprehensive entitlement: even women who may not have been in paid work were recognised in their own right - not as appendages of their husbands. We do not realise how radical all this is until we look internationally. Ireland, for example, has not been able to make this leap and many women do not get full pensions in their own right. In New Zealand there are no previous contributions required; no-fault assigned; no arguments that you should have taken better care or saved for yourself; and no penalty for marriage from a welfare type joint income test.

Complete rehabilitation: health often improves with security of a wage linked pension. NZ Super ensures full participation and belonging for all in old age while allowing choices to continue paid work. There is real compensation for the risk of longevity. The pension, if it had to be purchased with a capital sum at age 65 would be well beyond the means of virtually all older people.

Administrative efficiency: NZ Super is very simple; probably the simplest state pension system in the developed world and far cheaper to run than private sector savings schemes. There is: no discounts for good behaviour; no penalty for living too long; no division into deserving and undeserving; no corporation needed to administer it; and no actuarial based funding thinking.

Like the original ACC idea, NZ Super is extreme, and seemed too good to be true. However, while it suffered some political setbacks, the new paradigm was quickly embedded and popular with everyone, except economists. The first full on assault came in 1991 when the dominant free market economic paradigm was at its most virulent. We may forget, but the 1991 budget legislation passed

20 Geoffrey Palmer "Accident Compensation in New Zealand: The First Two Years" in The Welfare State Today: Social Welfare Policy in New Zealand in the Seventies (Fourth Estate Books, Wellington, 1977) 165. 
on budget night was to have made NZ Super a welfare benefit with a joint income test for couples. The intent was to encourage people to save privately and make it clear that it was welfare only for the poor. The outrage at this visionless attack and political power of the superannuitants got this legislation reversed. An accord in 1993 of multiparty support produced peace in our time. Compromise between those who saw it only for the poor and those who wanted it to be fully universal was reached, in the form of the surcharge on a person's other income that essentially clawed back only from high income people. ${ }^{21}$

NZ Super expenditure is very high compared to other parts of the welfare system, absorbing nearly one half of welfare spending and increasing automatically each year without the need to justify or debate the extra spending to accommodate wage growth and increased numbers. It is hard to fault NZ Super but the wasteful generosity to the well off is questionable as is the use of marital status and living arrangements as a basis for paying different amounts. Such is the power of the paradigm shift that it is very difficult to even raise options for modest cost containment by tweaking the tax system, as the Retirement Policy and Research Centre (RPRC) has done recently, without a deluge of outrage and misinterpretation. ${ }^{22}$

Unlike ACC, there have been few definitional problems that would necessitate judicial appeal. I am aware of only one problem that has been the subject of major unresolved court dispute. ${ }^{23}$ This case highlights my contention tonight that we are not good at resolving issues of equity in the courts, even when there are glaring inequities.

This is the spousal provision, whereby someone, usually a woman, who may have lived all her life in New Zealand, finds at age 65 that she is not entitled to a full NZ Super and in some cases no NZ Super, because of her husband's overseas pension. ${ }^{24}$ It has remained unresolved despite $10-15$ years of lobbying and is an obvious inequity. This illustrates nicely too that setting out the unassailable logic of an inequity is not enough to get action. Groups like the RPRC and the Retirement Commissioner have complained about this outright discrimination in the public arena for the past decade. In sheer desperation as a last resort and at huge personal cost, three superannuitants achieved a long and expensive hearing in the Human Rights Review Tribunal (HRRT). Sitting through the

21 See Susan St John "Superannuation in the 1990s: Where angels fear to tread?" in Jonathan Boston, Paul Dalziel and Susan St John (eds) Redesigning the Welfare State in New Zealand: Problems Policies Prospects (Oxford University Press, Auckland, 1999) 278.

22 Susan St John and Claire Dale Intergenerational impacts: the sustainability of New Zealand Superannuation (Retirement Policy and Research Centre, University of Auckland, 2019).

23 Charles Anderson "Nelson retiree takes overseas pension case to Human Rights Review Tribunal" (30 January 2017) Stuff <www.stuff.co.nz>.

24 Anderson, above n 23. 
obtuse arguments used by the Ministry of Social Development (MSD) and Crown Law to justify the clearly unjustifiable was a dismal experience. They are still waiting 18 months later for a decision.

Set against the multitude of extenuated litigation cases in ACC this case may seem trivial, but it illustrates the system's inertia and the entrenched attitudes to the assumed dependency of married or de facto women. Privately the politicians agree. In 2015 Rt Hon Jacinda Ardern denounced it in Parliament as a human rights violation. ${ }^{25}$ The Government eventually promised to fix it in the budget last year as the provision needed "modernisation" and the system should be moved towards "individualisation". But, not until next year and now apparently only if they get the legislation passed in time. Sadly, many have died while waiting for this small inexpensive policy tweak that would have made all the difference to their lives. There has been no talk of backpay or compensation when it is finally resolved. Justice delayed is justice denied.

\section{THE WELFARE SYSTEM}

The inspiration for the Social Security Act 1938 was the determination to end poverty in New Zealand. The aim of the Act was "to provide for ... Superannuation Benefits and other Benefits designed to safeguard the people of New Zealand from disabilities arising from age, sickness, widowhood, orphanhood, unemployment, or other exceptional circumstances ... and, further to provide such other benefits as may be necessary to maintain and promote the health and general welfare of the community". ${ }^{26}$

The Michael Joseph Savage vision did not survive the onslaught of neoliberal economics. From 1991 the intent was to change hearts and minds with a new paradigm called "Welfare that Works". The 1991 budget introduced benefit cuts, user pays/low tax and welfare confined to the poor by tightly targeted assistance only for those in "genuine need". The problems intensified when the purpose and principles of the Act were amended in 2007 to enshrine the role of paid work. This amendment under the then Labour Government mentions paid work nine times: ${ }^{27}$

The purpose and principles of the Social Security Amendment Act 2007 were: ${ }^{28}$

- to help people to support themselves and their dependents while not in paid employment;

- to help people to find or retain paid employment;

- to help people for whom work may not currently be appropriate because of sickness, injury, disability, or caring responsibilities, to support themselves and their dependents;

25 (25 March 2015) 704 NZPD 2623.

26 Alex McKenzie Social Assistance Chronology 1844 to 2019 (Ministry of Social Development, July 2019) at 46.

27 Social Security Amendment Act 2007.

28 Section 23. 
- work in paid employment offers the best opportunity for people to achieve social and economic well-being;

- $\quad$ the priority for people of working age should be to find and retain work;

- $\quad$ people for whom work may not currently be an appropriate outcome should be assisted to plan for work in the future and develop employment-focused skills; and

- $\quad$ people for whom work is not appropriate should be supported in accordance with the Act.

The purposes were to: ${ }^{29}$

- to enable in certain circumstances the provision of financial support to people to help alleviate hardship;

- to ensure that the financial support takes into account - that where appropriate they should use the resources available to them before seeking financial support under this Act; and

- to impose administrative and, where appropriate, work-related requirements on people seeking or receiving financial support under the Act.

The amendment paved the way for an attack not on poverty, but on welfare recipients. Between 2008 and 2017 a no holds barred reform approach placed a relentless focus on work, any work so long as it was paid work; a tighter targeting of assistance and sanctions for non-compliance. Using poverty as a weapon, Work and Income assumed wide powers, for example to determine what relationships would be counted as in the nature of marriage and what could be counted as income. An appeals process was stacked in MSD's favour; benefit fraud and disputed overpayments were conflated resulting even in the incarceration of women with children.

It is painfully clear that the welfare system of benefits is no longer fit for purpose. The indicators of social distress are all around us and I am not going to take time tonight to outline the breadth of this disaster. It is there for all to read in the \$2 million Whakamana Tangata 2019 report. ${ }^{30}$ The Welfare Expert Advisory Group argued for a paradigm shift - a change to the principles and purposes of the Social Security Act as the first step. It claimed the system is broken and needs $\$ 5.2$ billion more per year. Worryingly I have met few people who know anything about this report that so far has been buried.

The welfare system fails the five principles of Woodhouse miserably. It no longer prevents poverty, it creates and entrenches it. The idea of full participation and belonging for all is a pipe dream. People are urged to get a job, any job. Paid work is prioritised over work of any other kind, no matter how socially destructive. A climate of fear and "othering" of beneficiaries has been created. Work has been the only answer to poverty.

29 Section 23.

30 Welfare Expert Advisory Group Whakamana Tāngata: Restoring Dignity to Social Security in New Zealand (February 2019). 
The relationship basis of welfare payments is in desperate need of modernisation. Many do not get benefits if their partner is earning and the couple rate of benefit is miserably low. Marital status as determined by Work and Income penalises sole parents who try to re-partner. Children's tax credits are based on notions of the deserving and undeserving, so the poorest families do not get the full package of family assistance to alleviate their poverty.

Benefits are well below average wages, creating the need for a vast expansion of means-tested top ups and pressures on private charities and foodbanks. Data shows that beneficiaries owe $\$ 0.6$ billion of debt for so called "overpayments" and recoverable loans. This debt burdens already vulnerable people who may also need to borrow from loan sharks to stay afloat. There are no discounts for good behaviour, but damaging sanctions or so-called "bad behaviour". The system is highly complex and expensive to administer and police.

Individuals arguing their case for justice have been caught up in Kafkaesque-like experiences where unresponsive officials impose anachronistic rules and laws made for a different time and era. For those who do not cave in at this point, there may be appeals to the Benefit Review Committee, the Social Security Appeal Authority, and then the daunting prospect of higher courts. Some disappear for years in the labyrinth of the Office of Human Rights Proceedings (OHRP) and the Human Rights Review Tribunal (HRRT). While getting to a hearing in the HRRT can take years, after the hearing an actual decision can take many more years and even then, a finding of unlawful discrimination does not bind the Crown to reform the laws.

As the years drag by, the people affected lose their faith in truthfulness and rationality. They see their savings run down and with the unrelenting fight, they become sick and too often, may die without any resolution. Like the irrationality of the worst Kafka play, the state can wilfully withhold for years, even decades, the power to correct the things that are obviously and incontrovertibly wrong. That cannot be good for democracy.

Over the years I have followed or been involved with many such cases where issues have been unresolved for decades. The spousal provision already discussed tonight was one example.

Another is the Child Poverty Action Group (CPAG) legal case against discrimination in Working for Families. ${ }^{31}$ It was in desperation after trying all other rational means to get the policy changed that CPAG went to court ably represented, first by Cathy Rogers and Jenny Ryan, and then Frances Joychild QC. The case was heard in the HRRT in 2008 after six years of fighting just to establish the right to take the case. ${ }^{32}$ After appeal in the High Court the Judge found the policy to be discriminatory

31 Child Poverty Action Group "CPAG vs Attorney General: what did we gain?" (4 December 2015) <www.cpag.org.nz>.

32 Child Poverty Action Group Inc v Attorney-General [2008] NZHRRT 31. 
but let the government off the hook with weak arguments about justification. ${ }^{33}$ Various appeals, including an inadequate ruling from the Court of Appeal, ${ }^{34}$ saw CPAG take the issue into the court of public opinion rather than continue the expensive battle with the same narrow legal setting up to the Supreme Court. By 2019, the discrimination had cost the worst off families in New Zealand an accumulated sum approaching $\$ 8-10$ billion. Is it surprising that child poverty is so entrenched? Ultimately the removal of this discrimination is inevitable, because it is clear that this will provide a very cost-effective way to help meet the Government's child poverty reduction targets, but the harm to children of years of neglect by politicians cannot be readily forgiven.

And then there was Ms F who was investigated after an ex-partner vindictively dobbed her in, alleging she was not declaring income. I was pleased to see this case referred to by Sir Geoffrey in his lecture last year. ${ }^{35}$ This entailed an eight year battle in the courts for her to establish the patently obvious, that loans are not income and she should not have a $\$ 127,000$ debt. This landmark case taken for Ms F by Frances Joychild has not resulted in a wide investigation of injustices for other beneficiaries who have been treated similarly, or any assurance that the state is even interested in clarifying the legislation. Nor has the nasty practice of encouraging dobbing in, especially when by ex-partners, been denounced. So much for our system of improving policies. ${ }^{36}$

Then there is the case of Maree, a parent on her own with two young children, which further illustrates the neo-liberal obfuscation, and the impotency of legal processes to get better policy. ${ }^{37}$ She had few resources and had been supplementing her benefit with a small part-time job. She had an accident in 2000 that forced her to stop work completely in 2002. That meant she should have been entitled to some earnings-related compensation. After a long 8 year battle with ACC, she was awarded a gross amount of $\$ 89,000$ in backdated weekly compensation, which after being treated as income and her benefit abated should have given her $\$ 40,000$ or $\$ 5,000$ for each of these 8 years. Except that she was not given this at all, but only a token $\$ 576$, or just over a $\$ 72$ for each year, as her ACC was deducted dollar for dollar from her benefit because of a wrongheaded principle that says you cannot have benefits from both Work and Income and ACC.

33 Child Poverty Action Group Inc v Attorney-General HC Wellington CIV-2009-404-273, 25 October 2011.

34 Child Poverty Action Group Inc v Attorney-General [2013] NZCA 402, [2013] 3 NZLR 729.

35 Palmer, above n 4, at 417. See F v Chief Executive of the Ministry of Social Development [2018] NZHC 1607, [2018] 3 NZLR 260.

36 Susan St John "Dobbing in is a frightful blot on the face of a failed welfare system" (29 September 2018) The Daily Blog <https://thedailyblog.co.nz>.

37 Phil Pennington "ACC payout 'one benefit' law ruled discriminatory by Human Rights Tribunal" (5 February 2019) Radio New Zealand <www.rnz.co.nz>. 
It took five years for Maree's appeal to be heard in the HRRT. The decision, finally delivered recently, is a declaration that this is indeed unlawful discrimination. ${ }^{38}$ But after nearly two decades since the accident, in 2019 she will still get nothing because "the government department can't stop enforcing the law until the wording of the Social Security Act is changed". ${ }^{39}$ At least the government conceded the case, avoiding further court appeals, but in the meantime her dollar for dollar abatement has "caused years of severe financial strain for her and her family". ${ }^{40}$ It must be little consolation to Maree to hear Greg Robins, a senior solicitor at the OHRP, say "[i]t is disappointing that the abatement can't be reversed, but we are pleased she has won a clear declaration about the Social Security Act 1964 and the law that replaced it, the Social Security Act 2018."41 MSD will apparently "provide further advice to the Minister as required". 42

Finally there is Kathryn's story. Kathryn, after a shocking life of abuse and trauma, was imprisoned for the so-called crime of relationship fraud after being dobbed in by a vindictive expartner. Her children's lives were devastated and her health lost. CPAG commissioned barrister Catriona MacLennan to document the history of her life to show how the legal system needed to know far more before judging her to be in a relationship in the nature of marriage. ${ }^{43}$ Pleading not guilty and not showing remorse can result in severe penalty. When she was sent to prison in 2000 for six months, she had a vulnerable four year old and other distressed children. Her history shows she was suffering from PTSD because a former partner had killed her two year old, ten years before. The story of her life after the child's death is far worse than I have time to explain, but she was told to get into a stable relationship to get her children back. The new partner abused her children and Kathryn took him to court. The children were not believed and he later dobbed her in for being on a benefit while with him. On release from prison in 2001, MSD ordered Kathryn to repay $\$ 120,000$ they said she owed, out of her meagre benefit. MSD spent hundreds of thousands of dollars fighting her appeals against this debt, which were again brilliantly conducted by Frances Joychild QC. In 2019, the debt still hung over her even as a very ill beneficiary and was used against her when she needed hardship assistance from Work and Income. She died recently at the age of 58. Her PTSD should have been treated and she should have been fully rehabilitated and assisted. She should never have been found guilty in the first place. The government should have wiped the debt at very least.

38 Hennessy v Ministry of Social Development [2019] NZHRRT 4.

39 "Human Rights Review Tribunal declares MSD's ACC law discriminatory" The New Zealand Herald (online ed, Auckland, 4 February 2019).

40 "Human Rights Review Tribunal declares MSD's ACC law discriminatory", above n 39.

41 "Human Rights Review Tribunal declares MSD's ACC law discriminatory", above n 39.

42 "Human Rights Review Tribunal declares MSD's ACC law discriminatory", above n 39.

43 Catriona MacLennan Kathryn's Story: How the Government spent well over $\$ 100,000$ and 15 years pursuing a chronically-ill beneficiary mother for a debt she should not have (Child Poverty Action Group, June 2016). 


\section{THE NEXT PARADIGM SHIFT}

We cannot rely on marginal extensions to ACC produced by the adversarial court system to solve the very deep problems and injustices in the welfare system. We must not expect the judicial system to achieve the paradigm shift. We desperately need simplicity and clear purpose to bring the three schemes closer together: ${ }^{44}$

It was the simple coherence and attractiveness of the Woodhouse concept which in the end muted the criticism of its opponents. The scheme which no one asked for had an impetus of its own.

The next vision needs to look at NZ Super, ACC and welfare with one lens - the lens of maximising the wellbeing of each person. Appropriate goals are full rehabilitation, the prevention of disease, poverty and accidents and an adequate standard of living for everyone. The paradigm shift will challenge the traditional thinking and eliminate the trappings of private insurance and reliance on the courts.

If we know where we are going, over time we might get there. In the final few minutes, I can but pose a few suggestions of how the necessary paradigm shift may unfold. We may need a Royal Commission. Perhaps it will recommend an Income Maintenance and Wellbeing Commission based on Woodhouse principles for the 21 st century. For treatment and rehabilitation we could look to the Australian national disability scheme. We must move the three schemes of income maintenance closer together by challenging the sacred cows:

- couple-based welfare;

- $\quad$ earnings-related compensation;

- $\quad$ paid work focus as a source of value;

- universality of NZ Super; and

- unconscious bias against women.

NZ Super could become a basic income using the tax system to claw back from wealthy superannuitants much as Sir Geoffrey Palmer suggested in 1977. Then this basic income could be extended to the long term disabled and sick and then to other groups such as sole parents. ${ }^{45}$ While it may be viewed as absolute heresy, we do need to revisit the lottery of the earning related basis of ACC. The provision of an adequate basic income may suffice in most cases if full rehabilitation and treatment for accident and illness is at the heart.

44 Peter McKenzie "The Compensation Scheme No One Asked For: The Origins of ACC in New Zealand" (2003) 34 VUWLR 193 at 206.

45 St John and Dale, above n 21. 